\title{
Gambaran status besi pada pasien penyakit ginjal kronik stadium 5 dengan anemia yang menjalani hemodialisis reguler
}

\author{
${ }^{1}$ Bryan J. Silaban \\ ${ }^{2}$ Cerelia Sugeng \\ ${ }^{2}$ Bradley J. Waleleng
}

\author{
${ }^{1}$ Kandidat Skripsi Fakultas Kedokteran Universitas Sam Ratulangi Manado \\ ${ }^{2}$ Bagian/SMF Ilmu Penyakit Dalam Fakultas Kedokteran \\ Universitas Sam Ratulangi Manado \\ Email: bryanjsilaban@gmail.com
}

\begin{abstract}
Chronic kidney disease (CKD) is a pathological condition with a variety of etiology, resulting in progressively decreased renal function which is often ended with kidney failure. Chronic kidney disease has a global prevalence of 800 per million of population and the incidence of end-stage renal disease ranges from 150 to 200 per million of population. Complications often occur at the end-stage renal disease inter alia anemia with a rate of 80-90\%. This study was aimed to obtain the profile of stage-5 CKD patients with anemia and regular hemodialysis was performed on them. This was a descriptive-retrospective study using data of medical records at Prof. Dr. R. D. Kandou General Hospital from January 2015 to October 2016. There were six observed variables as follows: age, gender, serum iron (SI), total iron binding capacity (TIBC), transferrin saturation, and ferritin. The results showed that of the $48 \mathrm{CKD}$ patients with anemia, there were 24 males and 24 females. The majority were aged 60-69 years (33\%) and had normal SI level in 30 patients (67\%); decreased TIBC in 35 patients (75\%); normal transferrin saturation in 26 patients $(54 \%)$; and increased ferritin level in 38 patients (81\%). Conclusion: Majority of the patients were 60-69 years old and had normal level of SI, decreased TIBC, normal transferrin saturation, and increased levels of ferritin. There was no difference in case number of both sexes.
\end{abstract}

Keywords: serum iron, total iron binding capacity, transferrin saturation, ferritin

\begin{abstract}
Abstrak: Penyakit Ginjal Kronik (PGK) adalah suatu keadaan patologis dengan etiologi yang beragam, terjadi penurunan fungsi ginjal secara progresif, dan biasanya berakhir dengan gagal ginjal. Penyakit ginjal kronik merupakan salah satu masalah kesehatan di dunia dengan prevalensi 800 per juta populasi dan insidensi end-stage renal disease (ESRD) 150-200 per juta populasi di dunia. Komplikasi sering terjadi pada PGK stadium akhir antara lain anemia dengan persentase mencapai $80-90 \%$. Penelitian ini bertujuan untuk mendapatkan profil pasien PGK stadium 5 dengan anemia dan menjalani hemodialisis reglular. Jenis penelitian ialah deskriptifretrospektif menggunakan data sekunder dari catatan rekam medik periode Januari 2015 Oktober 2016 di RSUP Prof. Dr. R. D. Kandou Manado dengan enam variabel penelitian, yaitu usia, jenis kelamin, serum iron (SI), total iron binding capacity (TIBC), saturasi transferin, dan feritin. Dari 48 data rekam medik pasien yang memenuhi kriteria inklusi ditemukan bahwa mayoritas pasien berumur 60-69 tahun (33\%), laki-laki maupun perempuan berjumlah sama, mayoritas pasien memiliki kadar SI normal berjumlah 30 pasien (67\%), kadar TIBC menurun berjumlah 35 pasien $(75 \%)$, saturasi transferin normal berjumlah 26 pasien $(54 \%)$, dan kadar feritin meningkat berjumlah 38 pasien (81\%). Simpulan: Mayoritas pasien PGK stadium 5 yang menjalani hemodialisis reguler berusia 60-69 tahun, laki-laki dan perempuan berjumlah sama, serta memiliki kadar SI normal, penurunan TIBC, saturasi transferin normal, dan peningkatan kadar feritin.
\end{abstract}

Kata kunci: serum iron, total iron binding capacity, saturasi transferin, feritin 
Penyakit ginjal kronik (PGK) didefinisikan sebagai kerusakan ginjal yang terjadi lebih dari 3 bulan, berupa kelainan struktural atau fungsional dengan atau tanpa penurunan laju filtrasi glomerulus (LFG). Definisi lainnya yaitu penurunan LFG $<60$ $\mathrm{ml} / \mathrm{menit} / 1,73 \mathrm{~m}^{2}$ selama 3 bulan, dengan atau tanpa kerusakan ginjal. Etiologi PGK sangat bervariasi antara satu negara dengan negara lain. Di Amerika Serikat, insiden PGK akibat diabetes melitus menjadi yang terbesar yaitu 44\%. Data oleh Pernefri (2000) menunjukkan bahwa gagal ginjal di Indonesia disebabkan oleh glomerulonefritis (46,39\%), diabetes melitus $(18,65 \%)$, obstruksi dan infeksi $(12,85 \%)$, hipertensi $(8,46 \%)$, dan penyebab lain $(13,65 \%){ }^{1}$

Penyakit ginjal kronik merupakan salah satu masalah kesehatan di dunia, dimana prevalensinya di dunia adalah 800 per juta populasi dan insidensi End-Stage Renal Disease (ESRD) 150-200 per juta populasi. ${ }^{2}$ Di Amerika Serikat, data tahun 1995-1999 menyatakan insidensi PGK diperkirakan 100 kasus per juta penduduk per tahun, dan angka ini meningkat setiap tahunnya. Di negara-negara berkembang termasuk Indonesia, insidensi ini diperkirakan sekitar 40-60 kasus per juta penduduk per tahun. ${ }^{1}$ Menurut laporan Riset Kesehatan Dasar (Riskesdas) tahun 2013, prevalensi PGK di Indonesia ditemukan di Sulawesi Tenggara sebesar $0,5 \%$ dan untuk Sulawesi Utara dan Gorontalo sebesar $0,4 \%$., $^{3,4}$

Anemia merupakan salah satu komplikasi PGK yang penting karena memberikan kontribusi bermakna terhadap gejala dan komplikasi kardiovaskular pada PGK. Komplikasi ini dapat mulai terjadi pada penurunan fungsi ginjal yang masih awal, namun umumnya menjadi nyata bila LFG semakin menurun hingga $<30$ $\mathrm{ml} / \mathrm{menit}$. Menurut World Health Organization (WHO), seorang pasien dinyatakan anemia bila kadar $\mathrm{Hb}<13 \mathrm{~g} / \mathrm{dl}$ pada laki-laki dan $\mathrm{Hb}<12 \mathrm{~g} / \mathrm{dl}$ pada perempuan. ${ }^{5,6}$ Anemia terjadi pada $80-90 \%$ pasien PGK. Anemia pada pasien PGK terutama disebabkan oleh defisiensi eritropoietin. Hal-hal lain yang ikut berperan dalam terjadinya anemia adalah defisiensi besi, kehilangan darah (perdarahan saluran cerna, hematuria), masa hidup eritrosit yang pendek akibat terjadinya hemolisis, defisiensi asam folat, penekanan sumsum tulang oleh substansi uremik, dan proses inflamasi akut maupun kronik. $^{1,2}$

Prevalensi defisiensi besi pada penyakit ginjal kronik didapatkan sebesar 25-45\%. Pasien PGK yang mengalami kehilangan darah terutama pada pasien hemodialisis. Retensi darah pada dialiser dan blood tubing, perdarahan saluran cerna, pemberian antikoagulan dan antiplatelet memegang peranan penting. Selain itu, pemberian obat tertentu dapat mengganggu absorpsi besi seperti obat pengikat fosfat dan golongan proton pump inhibitors (PPIs). Disamping itu, pasien PGK yang menjalani hemodialisis sering mengalami inflamasi dan infeksi sehubungan dengan tindakan hemodialisis tersebut. Penilaian status besi pada PGK meliputi cadangan besi tubuh (ferritin serum) dan besi yang tersedia di sirkulasi untuk keperluan eritropoiesis (saturasi transferin). ${ }^{1,2,7,8}$

Sehubungan dengan hal tersebut di atas, penulis tertarik untuk melakukan penelitian tentang gambaran status besi anemia pada pasien penyakit ginjal kronik stadium 5 yang menjalani hemodialisis reguler karena penelitian ini belum pernah dilakukan sebelumnya. Penelitian ini didukung dengan adanya pasien penyakit ginjal kronik stadium 5 serta fasilitas hemodialisis serta transfusi darah di RSUP Prof. Dr. R. D. Kandou, Manado.

\section{METODE PENELITIAN}

Penelitian yang dilakukan bersifat deskriptif-retrospektif berdasarkan data sekunder dari catatan rekam medik. Penelitian dilakukan pada Oktober 2016 November 2016 di RSUP Prof. dr. R. D. Kandou, Manado. Subjek penelitian ini adalah data rekam medik pasien penyakit ginjal kronik stadium 5 dengan anemia yang menjalani hemodialisis reguler dan mendapat pemeriksaan status besi periode 
Januari 2015 - Oktober 2016 di RSUP Prof. dr. R. D. Kandou, Manado. Variabel penelitian antara lain umur, jenis kelamin, serum iron, total iron binding capacity, saturasi transferin, dan feritin. Pemeriksaan ini dilakukan dengan memeriksa catatan rekam medik. Data hasil pemeriksaan dimasukkan pada tabel yang telah disusun dengan Microsoft Word dan data diolah menggunakan Microsoft Excel.

\section{HASIL PENELITIAN}

Berdasarkan data rekam medik 48 pasien penyakit ginjal kronik stadium 5, didapatkan pasien terbanyak pada usia 6069 tahun diikuti 50-59 tahun, sedangkan yang paling sedikit pada usia $<20$ tahun (2\%) (Tabel 1).

Tabel 1. Distribusi pasien PGK stadium 5 berdasarkan usia

\begin{tabular}{ccc}
\hline Usia & $\mathbf{n}$ & $\mathbf{( \% )}$ \\
\hline$<20$ & 1 & 2 \\
$30-39$ & 4 & 8 \\
$40-49$ & 9 & 19 \\
$50-59$ & 10 & 21 \\
$60-69$ & 16 & 33 \\
$70-79$ & 8 & 17 \\
Total & 48 & 100 \\
\hline
\end{tabular}

Berdasarkan data rekam medik 48 pasien PGK stadium 5 didapatkan 24 pasien berjenis kelamin laki-laki (50\%) dan 24 pasien berjenis kelamin perempuan (50\%) (Tabel 2).

Tabel 2. Distribusi berdasarkan jenis kelamin.

\begin{tabular}{ccc}
\hline Jenis kelamin & $\mathbf{n}$ & $\mathbf{( \% )}$ \\
\hline Laki-laki & 24 & 50 \\
Perempuan & 24 & 50 \\
Total & 48 & 100 \\
\hline
\end{tabular}

Berdasarkan data rekam medik 48 pasien PGK stadium 5 didapatkan sebagian besar memperlilhatkan kadar serum iron normal yaitu 30 pasien (63\%) (Tabel 3).

Berdasarkan data rekam medik 48 pasien PGK stadium 5 didapatkan sebagian besar memperlihatkan total iron binding capacity (TIBC) menurun yaitu 35 pasien $(73 \%)$.
Tabel 3. Distribusi berdasarkan kadar serum iron (SI).

\begin{tabular}{ccc}
\hline Kadar SI & $\mathbf{n}$ & $\mathbf{( \% )}$ \\
\hline Menurun & 13 & 27 \\
Normal & 30 & 63 \\
Meningkat & 5 & 10 \\
Total & 48 & 100 \\
\hline
\end{tabular}

Tabel 4. Distribusi berdasarkan total iron binding capacity (TIBC).

\begin{tabular}{ccc}
\hline TIBC & n & $(\boldsymbol{\%})$ \\
\hline Menurun & 35 & 73 \\
Normal & 13 & 27 \\
Total & 48 & 100 \\
\hline
\end{tabular}

Berdasarkan data rekam medik 48 pasien PGK stadium 5 didapatkan sebagian besar memperlihatkan saturasi transferin normal yaitu 26 pasien (54\%) (Tabel 5).

Tabel 5. Distribusi berdasarkan saturasi transferin.

\begin{tabular}{ccc}
\hline Saturasi transferin & $\mathbf{n}$ & $\mathbf{( \% )}$ \\
\hline Menurun & 9 & 19 \\
Normal & 26 & 54 \\
Meningkat & 13 & 27 \\
Total & 48 & 100 \\
\hline
\end{tabular}

Berdasarkan data rekam medik 48 pasien PGK stadium 5 didapatkan sebagian besar memperlihatkan kadar feritin meningkat yaitu 39 pasien (81\%) (Tabel 6).

Tabel 6. Distribusi berdasarkan kadar feritin

\begin{tabular}{ccc}
\hline Kadar feritin & n & $\mathbf{( \% )}$ \\
\hline Menurun & 2 & 4 \\
Normal & 7 & 15 \\
Meningkat & 39 & 81 \\
Total & 48 & 100 \\
\hline
\end{tabular}

\section{BAHASAN}

Pada penelitian deskriptif-retrospektif berdasarkan catatan rekam medik pasien PGK stadium 5 dengan anemia yang menjalani hemodialisis reguler dan mendapat pemeriksaan status besi periode Januari 2015 - Oktober 2016 di RSUP Prof. Dr. R. D. Kandou Manado didapatkan 48 pasien yang memenuhi kriteria inklusi dan mengalami anemia. Hal ini sesuai dengan data yang dikumpulkan 
oleh Suwitra (2014) yang menunjukkan bahwa mayoritas pasien PGK mengalami anemia. ${ }^{1}$ Menurut data National Institute of Diabetes and Digestive and Kidney Diseases, anemia pada pasien PGK terutama disebabkan oleh defisiensi eritropoietin (EPO). Saat mengalami kerusakan, ginjal memroduksi EPO yang lebih sedikit sehingga produksi sel darah merah oleh sumsum tulang berkurang dan menyebabkan terjadinya anemia. ${ }^{9}$ Hal-hal lain yang ikut berperan dalam terjadinya anemia ialah defisiensi besi, kehilangan darah (perdarahan saluran cerna, hematuria), masa hidup eritrosit yang pendek akibat terjadinya hemolisis, defisiensi asam folat, penekanan sumsum tulang oleh substansi uremik, dan proses inflamasi akut maupun kronik. ${ }^{1,2}$ Penelitian yang dilakukan oleh Longnecker et al. membuktikan bahwa kehilangan darah akibat dialisis mencapai 5-7 liter per tahun. ${ }^{10,11}$

Berdasarkan data rekam medik 48 pasien penyakit ginjal kronik stadium 5 ini, didapatkan kelompok usia terbanyak ialah 60-69 tahun (33\%). Menurut data yang dikumpulkan oleh Pernefri, diperkirakan terdapat 70.000 penderita PGK di Indonesia dan salah satu faktor risiko terjadinya penyakit ini ialah penuaan, karena LFG menurun seiring bertambahnya usia. $^{12,13}$

Berdasarkan data rekam medik 48 pasien PGK stadium 5, didapatkan 24 pasien berjenis kelamin laki-laki (50\%) dan 24 pasien berjenis kelamin perempuan $(50 \%)$. Hal ini tidak sejalan dengan data yang dikumpulkan oleh Riskesdas (2013) yang menunjukkan bahwa pasien PGK lebih banyak terdapat pada laki-laki dibandingkan perempuan.,

Berdasarkan data rekam medik 48 pasien PGK stadium 5 ini, didapatkan kadar serum iron menurun pada 13 pasien (27\%). Hal ini sesuai dengan penelitian yang dilakukan serta data yang dikumpulkan oleh Devkota (2014), Brittenham (2013), dan American Association for Clinical Chemistry yang menunjukkan bahwa penurunan SI ditemukan pada anemia defisiensi besi, sindrom nefrotik, PGK, infeksi, hipotiroidisme, dan keganasan. ${ }^{14-16}$ Dalam penelitian ini juga ditemukan kadar SI normal pada 30 pasien (63\%) dan kadar SI meningkat pada 5 pasien $(10 \%)$. Hal ini bisa terjadi sebagai respon pemberian eritropoietin (EPO) pada pasien-pasien PGK. ${ }^{17}$ Peningkatan SI juga bisa terjadi bila pasien menjalani transfusi berulang sehingga terjadi penimbunan besi atau hemosiderosis. ${ }^{16,18,19}$

Berdasarkan total iron binding capacity (TIBC), didapatkan TIBC menurun pada 35 pasien (73\%). Hal ini sesuai dengan data-data yang dikumpulkan oleh Devkota (2014) yang menunjukkan bahwa penurunan TIBC ditemukan pada hemokromatosis, hemosiderosis, talasemia, hipertiroidisme, sindrom nefrotik, dan anemia pada penyakit kronik. $^{20}$ TIBC rendah pada anemia pada penyakit kronik dikarenakan jumlah cadangan besi (feritin) yang cukup, namun tidak cukup tersedia dalam peredaran darah (serum iron). Menurut data Iron Disorders Institute, TIBC cenderung meningkat saat cadangan besi menurun. Sebaliknya, TIBC cenderung menurun saat cadangan besi meningkat. Pada anemia defisiensi besi, TIBC bernilai $400-450 \mu / \mathrm{dl}$ karena cadangan besi menurun. $^{21-23}$

Berdasarkan saturasi transferin, didapatkan saturasi transferin menurun pada 9 pasien (19\%). Hal ini sesuai dengan penelitian yang dilakukan serta data-data yang dikumpulkan oleh Paruthi (2016) yang menunjukkan bahwa saturasi transferin kurang dari $20 \%$ menunjukkan adanya defisiensi besi. Saturasi transferin yang rendah sering ditemukan pada penyakit infeksi kronik, keganasan, inflamasi, uremia, dan sindrom nefrotik. Pada PGK, terjadi penurunan saturasi transferin. ${ }^{24}$ Dalam penelitian ini juga ditemukan saturasi transferin normal pada 26 pasien $(54 \%)$ dan saturasi transferin meningkat pada 13 pasien $(27 \%)$. Hal ini bisa terjadi sebagai respon pemberian eritropoietin (EPO) pada pasien-pasien PGK. ${ }^{17}$ Peningkatan saturasi transferin juga bisa terjadi apabila pasien menjalani 
transfusi berulang sehingga terjadi
penimbunan besi atau hemosiderosis. ${ }^{24-26}$

Berdasarkan kadar feritin, didapatkan kadar feritin meningkat pada 39 pasien $(81 \%)$. Hal ini sesuai dengan penelitian yang dilakukan serta data-data yang dikumpulkan oleh Devkota (2014) yang menunjukkan bahwa peningkatan feritin ditemukan pada penyakit hati, infeksi, inflamasi, alkoholisme, keganasan, hipertiroidisme, Gaucher disease, infeksi miokardial, hemokromatosis, ESRD, anemia selain anemia defisiensi besi. ${ }^{27}$ Peningkatan tinggi serum feritin (>2000 $\mu \mathrm{g} / \mathrm{dl})$, biasanya mengindikasikan terjadinya penimbunan besi ( $\mathrm{Fe}$ overload) yang dikenal sebagai hemosiderosis. ${ }^{28,29}$ Namun, kasus-kasus hemosiderosis pada pasien yang menjalani dialisis kebanyakan berasal dari era sebelum terapi erythropoiesisstimulating agent (ESA) dimana transfusi darah lebih sering digunakan sebagai terapi anemia. Pada kebanyakan pasien hemosiderosis, serum feritin bernilai 2.000$10.000 \mu \mathrm{g} / \mathrm{dl}$ atau bahkan lebih tinggi. ${ }^{30-32}$ Peningkatan sedang serum feritin (tidak lebih dari $2000 \mu \mathrm{g} / \mathrm{dl}$ ) ditemukan tidak berhubungan dengan peningkatan $\mathrm{Fe}$ jaringan. Hal ini dibuktikan melalui autopsi dan penelitian oleh Gokal et al. (1979). ${ }^{32}$ Pada pasien PGK, hiperferitinemia berhubungan dengan kurang responsifnya pasien terhadap terapi ESA. ${ }^{33,34}$ Penelitian oleh Kirschbaum ${ }^{35}$ membuktikan bahwa $34 \%$ dari pasien-pasien penyakit ginjal kronik yang menjalani hemodialisis reguler yang mengalami peningkatan serum feritin mengalami inflamasi. Hal inilah yang menjadi faktor penyebab meningkatnya feritin. Pada PGK stadium 5 (ESRD), terjadi peningkatan feritin. ${ }^{27}$

\section{SIMPULAN}

Berdasarkan hasil penelitian terhadap pasien penyakit ginjal kronik stadium 5 dengan anemia yang menjalani hemodialisis reguler periode Januari 2015Oktober 2016 di RSUP Prof. Dr. R. D. Kandou Manado dapat disimpulkan bahwa mayoritas berusia 60-69 tahun dengan kadar serum iron (SI) normal, penurunan total iron binding capacity (TIBC), saturasi transferin normal, dan peningkatan kadar feritin. Tidak terdapat perbedaan kejadian antara kedua jenis kelamin.

\section{SARAN}

1. Pemeriksaan status besi sebaiknya diwajibkan bagi setiap pasien penyakit ginjal kronik stadium 5 agar gambaran status besi pasien bisa diketahui dan membantu penilaian keberhasilan terapi.

2. Hasil penelitian ini diharapkan bermanfaat sebagai sumber data dan informasi bagi penelitian selanjutnya.

\section{DAFTAR PUSTAKA}

1. Suwitra K. Penyakit ginjal kronik. In: Setiati S, Alwi I, Sudoyo AW, Simadibrata M, Setiyohadi B, Syam AF, editors. Buku Ajar Ilmu Penyakit Dalam (6th ed). Jakarta: Interna Publishing, 2014; p. 2159-65.

2. Said SK, Hany SE, Mahmoud ME, Enas SE, Ahmed AZ. Study of possible correlation between inflammation and bone mineral disorders in chronic kidney disease. IJRSR. 2014;5:125661.

3. O'Callagan C. Gagal ginjal kronik dan renal bone diseases. At a glance: Sistem Ginjal (2nd ed). Jakarta: Erlangga, 2007; p. 92-3.

4. Patambo K. Gambaran status besi pada penderita penyakit ginjal kronik yang menjalani hemodialisis. eCl. 2014;2(2):25-6.

5. Guyton CA, Hall JE. Penyakit ginjal kronik dan diuretik. Buku Ajar Fisiologi Kedokteran (11th ed). Jakarta: EGC, 2007; p. 426.

6. World Health Organization. Haemoglobin concentrations for the diagnosis of anaemia and assessment of severity. 2011.

7. Universitas Diponegoro. Penyakit ginjal kronik. [cited 2016 Nov 23]. Available from:

http://eprints.undip.ac.id/44532/3/Dhan ny_Candra_A_22010110120112_Bab2 KTI.pdf

8. Universitas Sumatera Utara. Anemia pada penyakit ginjal kronik. [cited 2016 Nov 16]. Available from: 
http://repository.usu.ac.id/bitstream/123 456789/33498/4/Chapter\%20II.pdf

9. National Institute of Diabetes and Digestive and Kidney Diseases. Anemia in chronic kidney disease. [cited 2016 Nov 16]. Available from: https://www.niddk.nih.gov/healthinformation/health-topics/kidneydisease/anemia-in-kidney-disease-anddialysis/Pages/facts.aspx

10. Longnecker RE, Goffinet JA, Hendler ED. Blood loss during maintenance hemodialysis. Trans Am Soc Artif Intern Organs. 1974;20A:135-40.

11. Lindsay RM, Burton JA, Edward N, Dargie HJ, Prentice CRM, Kennedy AC. Dialyzer blood loss. Clin Nephrol. 1973;1:29-34.

12. Tandi M. Hubungan antara derajat penyakit ginjal kronik dengan nilai agregasi trombosit. eBM. 2014;2(2):509-12.

13. Hidayati T, Kushadiwijaya H, Suhardi. Hubungan antara hipertensi, merokok, dan minuman suplemen energi dan kejadian penyakit ginjal kronik. J BKM. 2008;24(2):90-102.

14. Devkota BP. Iron. 2014 Jan 17 [cited 2016 Sep 11]. Available from: http://reference.medscape.com/refarticl e-srch/2085704-overview

15. U.S. National Library Of Medicine. Iron. [cited 2016 Nov 15]. Available from: https://medlineplus.gov/iron.html

16. Brittenham GM. Disorders of iron homeostasis: iron deficiency and overload. In: Hoffman R, Benz EJ Jr, Silberstein LE, et al, editors. Hematology: Basic Principles and Practice (6th ed). Philadelphia, PA: Elsevier Saunders, 2013; p. c. 34.

17. Kalantar-Zadeh K, Regidor DL, McAllister CJ, Michael B, Warnock DG. Time-dependent associations between iron and mortality in hemodialysis patients. J Am Soc Nephrol. 2005;16(10):3070-80.

18. Napchan GD. Hemosiderosis. 2015 Jan 14 [cited 2016 Sep 11]. Available from: http://reference.medscape.com/refarticl e-srch/1002002-overview

19. Mir MA. Transfusion-induced iron overload. 2014 Mar 10 [cited 2016 Sep 11]. Available from: http://reference.medscape.com/refarticl e-srch/1389732-overview
20. Devkota BP. Iron binding capacity. 2014 Jan 16 [cited 2016 Sep 11]. Available from: http://reference.medscape.com/refarticl e-srch/2085726-overview

21. Iron Disorders Institute. Anemia of chronic disease. [cited 2016 Nov 16]. Available from:

http://www.irondisorders.org/anemiaof-chronic-disease

22. Kalantar-Zadeh K, Kleiner M, Dunne E, Ahern K, Nelson M, Koslowe R, et al. Total iron-binding capacity-estimated transferrin correlates with the nutritional subjective global assessment in hemodialysis patients. Am J Kidney Dis. 1998;31:263-72.

23. Kalantar-Zadeh K, Kalantar-Zadeh K, Lee GH. The fascinating but deceptive ferritin: to measure it or not to measure it in chronic kidney disease. Clin J Am Soc Nephrol. 2006;1(suppl 1):S9-S18.

24. Paruthi S. Transferrin saturation. 2015 Jan 14 [cited 2016 Sep 11]. Available from: $\mathrm{http} / / /$ reference.medscape.com/refarticl e-srch/2087960-overview

25. Willczynski C. Transferrin receptor. 2014 Feb 12 [cited 2016 Sep 11]. Available from:

http://reference.medscape.com/refarticl e-srch/2086300-overview

26. U.S. National Library Of Medicine. Total iron binding capacity. [cited 2016 Sep 11]. Available from:

https://medlineplus.gov/ency/article/00 3489.htm

27. Devkota BP. Ferritin. 2014 Jan 16 [cited 2016 Sep 11]. Available from: http://reference.medscape.com/refarticl e-srch/2085454-overview

28. Kalantar-Zadeh K, Rodriguez RA, Humphreys MH. Association between serum ferritin and measures of inflammation, nutrition and iron in haemodialysis patients. Nephrol Dial Transplant. 2004;19:141-9.

29. Powell LW, George DK, McDonnell SM, Kowdley KV. Diagnosis of hemochromatosis. Ann Intern Med. 1998;129:925-31.

30. Winchester JF. Management of iron overload in dialysis patients. Semin Nephrol. 1986;6:22-6.

31. Barany P, Eriksson LC, Hultcrantz R, Pettersson E, Bergstrom J. Serum ferritin and tissue iron in anemic 
dialysis patients. Miner Electrolyte Metab. 1997;23:273-6.

32. Gokal R, Millard PR, Weatherall DJ, Callender ST, Ledingham JG, Oliver DO. Iron metabolism in haemodialysis patients. A study of the management of iron therapy and overload. Q J Med. 1979;48:369-91.

33. Gunnell J, Yeun JY, Depner TA, Kaysen GA. Acute-phase response predicts erythropoietin resistance in hemodialysis and peritoneal dialysis patients. Am J Kidney Dis. 1999;33:6372.

34. Bailie GR, Frankenfield DL, Prowant BF, McClellan W, Rocco MV. Erythropoietin and iron use in peritoneal dialysis patients. Report from the 1997 HCFA end-stage renal disease core indicators project. Am J Kidney Dis. 1999;33:1187-89.

35. Kirchbaum B: Profiling hemodialysis patients with high ferritin levels. Clin Nephrol56 :117- 123,2001. 